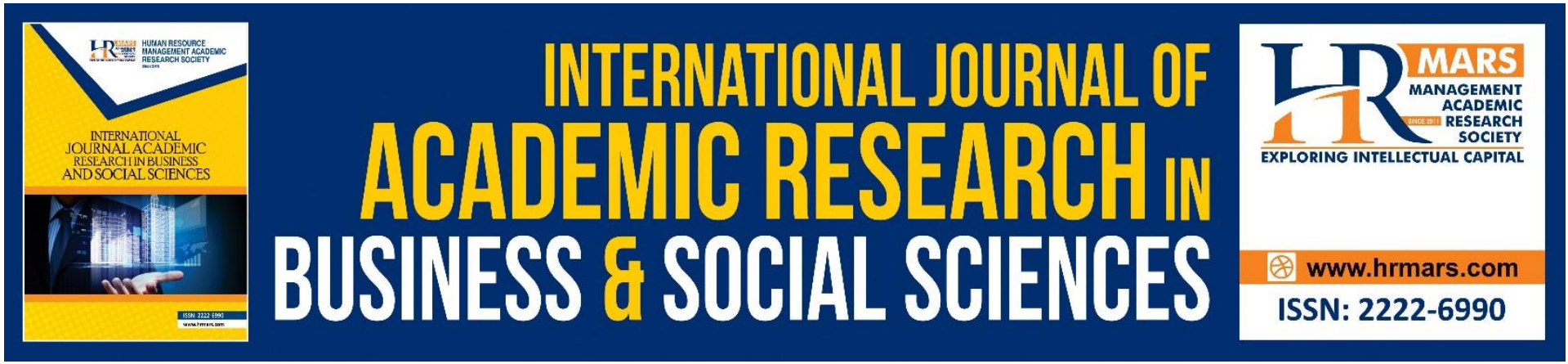

\title{
Millennial Teachers' Use of Technology in ESL Classroom: A Review of Literature
}

Nishantini Loganathan, Harwati Hashim

To Link this Article: http://dx.doi.org/10.6007/IJARBSS/v10-i12/8098

DOI:10.6007/IJARBSS/v10-i12/8098

Received: 03 November 2020, Revised: 27 November 2020, Accepted: 18 December 2020

Published Online: 30 December 2020

In-Text Citation: (Loganathan \& Hashim, 2020)

To Cite this Article: Loganathan, N., \& Hashim, H. (2020). Millennial Teachers' Use of Technology in ESL Classroom: A Review of Literature. International Journal of Academic Research in Business and Social Sciences, 10(12), 907-923.

Copyright: (c) 2020 The Author(s)

Published by Human Resource Management Academic Research Society (www.hrmars.com)

This article is published under the Creative Commons Attribution (CC BY 4.0) license. Anyone may reproduce, distribute, translate and create derivative works of this article (for both commercial and non-commercial purposes), subject to full attribution to the original publication and authors. The full terms of this license may be seen at: http://creativecommons.org/licences/by/4.0/legalcode

Vol. 10, No. 12, 2020, Pg. 907 - 923

Full Terms \& Conditions of access and use can be found at http://hrmars.com/index.php/pages/detail/publication-ethics 




\title{
Millennial Teachers' Use of Technology in ESL Classroom: A Review of Literature
}

\author{
Nishantini Loganathan, Harwati Hashim \\ Faculty of Education, Universiti Kebangsaan Malaysia
}

\begin{abstract}
Although there is an explosion of technology readily available for teaching and learning, questions arise as to why online learning is not effective especially during pandemic times like now due to Covid-19. This brings to the ultimate question of what technology does the millennial teachers use in ESL classroom. This is because, owing to the time that this generation has grown up in, this Net generation is also known to be accustomed using technology easily and at ease. A systematic literature review is thus conducted to review the gap that exists in researches between millennial teachers and technology, concept of millennial teachers, what technology tools are and also the effects of integrating technology in ESL classroom. Through this review the use of technology in ESL classroom in terms of advantages and disadvantages and concept of millennial teachers in Malaysia was discussed and defined. The findings from the review shall serve as the base or guideline for future studies related to millennial teachers and the use of technology.
\end{abstract}

Keywords: Millennial Teachers, Technology Tools, EsI Classroom, The Use Of Technology For Esl Learning, Acceptance.

\section{Introduction}

World today is already in the beginning of the fourth industrial revolution (IR 4.0) which is ultimately altering every living entities' way of living, working and communicating through its technology revolution (Schwab, 2016). The exponential growth of emerging technologies is indeed one of the megatrends that dominates and defines the fourth industrial revolution as well as the world today (Modly, 2016; Gupta et al., 2019). Irrefutably, education has become one of the primary directions of discussion in IR 4.0 era since education is one of the factor that determines the competency of a country at dealing IR4.0. This is because, the productivity and economy of a country relies on the next generation's credibility to navigate the digital world to which education is one of the vital keys (Anderson, 2017; Ball, 2017).

Extensive researches were conducted in relation to technology in education from year 1962 to 2020 (Based on Scopus database) alone. This signifies the growing interest in the research field relating to technology in education. However, Covid-19, the current issue that the world is facing since the beginning of 2020 documented the plethora of challenges that governments, schools, teachers, parents and especially students are facing with the sudden halt to education as we know before. This is because the only plausible method to contain 
the novel virus involved Movement Control Order which has interrupted learning for learners up to 7 million from preschool to tertiary level (UNESCO, 2020).

Although distance learning has been suggested to ensure the continuity of learning, technology has become the biggest challenge for not just learners and teachers but also for parents. HundrED.Org, a non-profitable organization seeking to improve education across the world has identified 10 significant problems faced by learners, educators and parents during Covid-19. It was identified that a surplus of resources are disclosed but without detailed directives on how to employ and exploit them followed by issues like teachers struggling to go digital without much support and training (Petrie et al., 2020). A further survey was also conducted by HunDred on $2^{\text {nd }}$ April 2020 to understand continuity of education during crisis. Akin to the problems identified, the survey too highlighted that $6 \%$ of the participants only alleged that their education system was greatly equipped for the contagion. Further inquiry has also brought up concerns around inadequate access to technology and teachers' aptitude to adjust in the new norm of teaching. The report further alluded that teachers are in for no options for a system that is not prepared and thus are far from implementing best practices for 'online learning' and so are struggling for 'emergency online homeschooling' (Milligan, 2020; Lehmann, 2020b; Guzdial, 2020 as cited in Petrie et al., 2020).

Probing further on the note, it is pinpointed that the usage of technology is still limited among teachers and at some extent; certain teachers still show deficit level of capability when it comes to using technology software like Ms. PowerPoint or Ms. Excel (Safitry, et.al 2015, Moganashwari \& Parilah, 2013). Based on past researches, it is also found among the main factors are teachers' lack exposure (knowledge and skills) and choice on different instructional practices (Johnson, Jacovina, Russell, \& Soto, 2016, Boulter, 2007, Melor 2007, Sridharan et.al, 2010). This is in line with OECD's report which reported hitches in identifying effective and quality digital learning resources from among a surfeit of mediocre ones and scarce pedagogical preparation for amalgamating technology meaningfully into teaching and learning, create a wedge between potentials and actuality (OECD, 2016).

Granting the impressive researches that have been carried out to understand technology, from both students and teachers' perspectives in the aspects of benefits, issues, challenges, attitudes and knowledge, researches on digital resources used by millennial teachers are not explored. Most researches focus on teachers' perspectives and attitude on the usage of technology but few focuses on solution for problems that come to light due to the deficiency of exposure and knowledge on techniques to apply ICT and the information about software, tools and website to support teaching (Seward \& Nguyen, 2019, Safitry, et.al 2015). Consequently, many researchers concluded that easy access to empirically authenticated educational technologies is crucial for effective implementation of technology in classroom (Carver, 2016, Kamau, et.al, 2018). Therefore, millennial teachers' perspectives and practices need to be explored since the world is soon to be dominated by millennial who are more tech savvy (Tate, 2019, Lourenco \& Cronan, 2017). Exploring their perspectives and practices will help other teachers to identify the right technology which is already been used and validated by other teachers (Moganashwari \& Parilah, 2013). Henceforth, this paper looks into i)concepts relevant to millennial teachers' ii)technology tools in ESL classroom which is broken down to few sections respectively; technology tools, the use of technology tools in ESL classroom, past researches relavant to the use of technology tools which discusses the advantages, disadvantges of using technology tools and finally issues and challenges related to the use of technology tools in ESL classroom. With the literature gathered, future studies on currently available and effective technology tools that have been used, explored and thus 
validated by millennial teachers, could be explored and therefore distance learning could be embraced by exploiting the educational technology tools.

\section{Millennial Teachers}

Millennial generation has a trademark that distinguishes them as a cohort that matured alongside with technology. However, there is no definite clause that points out who the millennials are based on the portion or span of time born according to Bracy et al., (2010) because different researches identify millennial generation as born of different range of years. For an instance, Oblinger and Oblinger (2005) classified millennial generation as borns from 1983 to 1991, Howe \& Strauss (2000) 1982 to 1994, Best et al. (2013) 1982-1994, Lourenco and Cronan (2017) 1980 to 2000 and Tate (2019) asserted that millenials are born from 1980 s and beyond. Therefore, to better understand the millennial generation, introduction of technology in Malaysia has to be understood and defined. Because understanding the introduction of technology in Malaysia will help in determining and shortlisting the right population of the millennial generation.

As it has been fathomed, technology started to pave and weave its way to almost every aspect of human's life, nation and world. Malaysia was no exception either and thus the gale of technology began to hit Malaysia in 1980s (Andin \& Ali, 2010; David et al., 1990; Lateh \& Muniandy, 2010; Malaysia, 2000; Salman \& Hasim, 2011). Understanding the significance of technology as one of the core impetuses for the nation's economy, the Malaysian government had embarked on various transformations to boost, strengthen and embrace the digital revolution to ensure that the nation will be on par with other first world countries. And it is undeniable that the Malaysian government's involvement in technology's progress in Malaysia is commendable with its various policies, budget allocations and programs that has indeed had heightened and accelerated technology integration in Malaysia. Based on the researcher's reading, a chronology of the Malaysian's technology development is outlined below. 




Figure 1 Chronology of technology development in Malaysia

The flowchart above is the simplified history of technology development in Malaysia. Based on Figure 1, it can be concluded that technology began influencing Malaysians in the beginning of 1980s where teachers were trained and equipped with knowledge on computer education to impart the knowledge learnt to the students. As teachers are trained to become agents of change in computer education, guidelines on formation of computer and introduction to computers are initiated by the government. Soon after, pilot projects are commenced in 1986, thus initiating the start of computer and technology education in Malaysian schools. And looking at the chronology it is understood that various measurements like projects and policies were and are still being executed in Malaysia to ensure that Malaysians are technology literate which is believed to have direct connection to the economy of the nation. This information indicates that the millennial generation in Malaysia are those who are born in early 1980s, specifically 1983 since computers were introduced in they are born. Hence, the word computer or technology would have not been alien to them. On such ground, Oblinger and Oblinger (2005) classification of millennial generation will be referred in this study. Based on the classification, millennial generation in Malaysia would be in the age group of 37 years to 29 years of old as of 2020 and 36 years to 28 years in the year of 2019. Based on the statistics published by Department of Statistic in Malaysia for teachers in 2019, 28 year olds fall under the 25-29 years category with a total of 32,294 teachers, in the 30-34 year old teachers' category is 57,611 teachers and in the 35-39 year olds category there were about 89,262 teachers in both primary and secondary schools for all three categories (Malaysian Educational Statistics, 2019).

Now that the age group of this generation is classified, it is essential to have a grasp on the characteristics of this generation that distinguishes them as Generation $Y$ or also known as Generation Net. According to Oblinger and Oblinger (2005), distinctive attribute of 
this generation is that they are optimistic and strong-minded. They prefer the latest technology and detest anything that is dawdling and pessimistic. On the other hand, Oblinger and Oblinger (2005) also implied a metaphor that compared internet to oxygen for this generation since they cannot live without it. It was also implied that individuals of millennial generation are avid consumers of information technology in their education and personal lives who observes internet as an open platform for accessing the plethora of resources instead of a medium with restrictions. It was also reported that, the millennials exhibit a tendency to work in groups. They would be able to have valuable, personal and meaningful conversations and interactions physically, virtually and even hybrid situation as technology is also used to expand their social network.

When it comes to education, this generation likes experiential learning that involves interaction. This can be obtained from digital resources which provide raw materials for learning. The reason behind this choice is because millennials prefer to construct own learning by assembling information, tools and frameworks from different sources instead of traditional learning which involves being spoon-fed. This makes this generation, a group of students who are independent and responsible as claimed by Noguera (2014) and Alexander (2012). This means that the Gen $Y$ takes responsibility of their own learning making them autonomous learners who take active charge in constructing their knowledge. This is supported by Kotz (2016) who asserted that millennials prefer to be actively involved in class and also to be active thinkers. Immediacy is the next attribute that best describes this generation (Celi, 2019). The millennials are able to multitask and prefer immediate gratification as they want information now and quickly (Schwartz et al., 2018). This explains their dislike for anything that is slow, especially slow internet connection. When looked into the matter, the reason behind the immediacy is the fact that this generation from their early years has been exposed to multiple media types. Therefore, it could be said with certainty that technology has altered this special generation to be technology dependent.

On the other hand, Lourenco and Cronan (2017) assert that millennials are called 'digital natives,' because they grew up with a wide range of technology and are used to having convenient accessibility to a vast spectrum of information, and are not prone to waiting for any of that information. This generation were raised up at a time when technology had made it possible to make significant contributions from almost anywhere. This has also been agreed by Tate (2019) who explained that growing up with technology in their surrounding had allowed this generation to operate their individual daily functions impulsively with technology. Layton (2015) explained that technology has always been there in the lives of this generation whereby social networking and information has always been right at the click of their fingertips. The dependency on technology attribute is further explored by Johnson (2006) who acknowledged that millennial generation made team orientation possible through online. All the characteristics defined are made possible with technology hence proving the interrelatedness of millennial generation with technology.

Having a clear view on millennial generation will now help in exploring the idea of millennial teachers. It is important to look into millennial teachers as this group of teachers is ready to take over the position of most of the generation $X$ teachers who are already retiring and are about to retire (Bartz et al., 2017). This is supported by Meister and Wilyerd (2010) whom predicted that the generation Y will include 74\% of the employees by 2025 and also Shulyakovskaya (2016) whom also anticipated that the millennials will make up about $75 \%$ of the workforce by 2025 . Besides, Tate(2019) stated in her study that $44 \%$ of millennial teachers have already joined the teaching force. Therefore, discovering who the millennial teachers 
are will very much help teachers of other generation to learn one or two essential knowledge that would definitely help them in enhancing their teaching practices.

It is an unquestionable fact that millennials are equivalent to technology. Hence, it is no surprise that the millennial teachers are defined as digitally conscious teachers who are able to use technology as a medium of instruction in their teaching and learning. The millennial teachers are also described as individuals who recognize the significance of amalgamating technology for their students. The millennial teachers' higher aptitude towards technology has enhanced their credibility in accepting diversity, inclusion and changes in using technology. And their dislike for slow technology is the reason behind their immediacy in speeding up their communication using technologies like emails, texts and social media (Bartz et al., 2017). Shulyakovskaya (2016) conversely emphasized that educators from this generation are motivated to be novel, advanced and creative with their curriculum and teaching practices. This is also buttressed by Layton (2015) as she clarified that millennial teachers are greatly progressed in technology, innovative in designing their lessons and wish to incorporate fun in their classroom and work environment. Whereas Greenebaum (2009) illustrated teachers of this generation to be used to and anticipate innovation and continuous learning using technology.

As mentioned earlier, individuals of millennial generation would not remember a day without technology, hence they are very much capable of discovering and employing technology mediums and media tools to enhance learning process (Oomen-Early \& Early, 2015) making it a limelight feature of teachers as teachers are required to make new changes in $21^{\text {st }}$ century classroom instead of being sage on the stage. Since technology is a norm and not something that they have to learn, a lot can be learnt from this group of people as been pointed out by Lourenco and Cronan (2017) who claimed that this generation would make as efficient "tech teachers". Based on the analysis done on who the millennials are and their function and credibility as teachers, it is justified that millennial teachers do have so much to offer in developing the teaching and learning practices, especially now that certain teachers and majority of students are struggling to continue their learning due to Covid-19. As appraised by Lourenco and Cronan (2017), scrutinizing millennial teachers everyday teaching and learning practices or lessons would definitely be an eye opener, enlighten and support other teachers to boost their own teaching and instructions as well.

\section{Technology Tools in ESL Classroom Technology Tools}

It is a known fact that technology has spun its web into almost every aspect of life as acknowledged by Md Yunus et al., (2020) and that the major impact could be seen in education which is a driving key factor in improving the economy of a country. In the process of integrating technology in education, various revamps have been planned and implemented. And this has brought to light, buzzwords like technology in education, technology tools, $21^{\text {st }}$ century learning, active learning and collaborative learning. A study by Hashim et al., (2019), highlighted information communication and technology (ICT) having various roles including one as an educational tool which are commonly used to scrutinize and supplement teaching and learning process. The authors too acknowledged online games as effective tool in learning where it is used as an emulous platform with linguistic elements to excite effective lesson delivery. With the introduction of technology, therefore a myriad of technology tools have emerged worldwide for both educators and learners to opt in making the teaching and learning more interesting, captivating, effective and meaningful. 
Technology tools according to Light \& Polin (2010) and Md Yunus \& Suliman, (2014) is also referred as media practices and tools which includes websites, blogs, web based applications, open learning platform and even virtual platforms. This is also supported by Passmore (2020), where technology tools was referred to as software that have evolved over time, which can also be operated to expand or support online program content including tools that are readily accessible through the internet. It is also deemed to make instructions and learning more efficient. Technology tools was also acknowledged as computer and mobile technologies that have the capability to increase learning of language by Hashim et al., (2016). Besides, technology tools have also earmarked the introduction of digital games which are a part of educational games. Henceforth, it can also be demarcated as digital applications controlled through phone, tablet, computer or console (Masrop et al., 2019). Moreover, social media is also seen as part of technology whereby students and teachers are allowed to connect and interact to barter ideas through collaboration and discourses (Pazilah et al., 2019). Through this it could be understood that technology tools are not limited to devices and websites alone but also include software, courseware, applications and also equipment like television and LCD.

On the other hand, technology tools were highlighted as a progress tracker which allows for immediate feedbacks, interactivity that promotes better retention of knowledge through the active participation (Santa Dedo \& Hashim, 2019). Besides, in a research conducted by Ahmadi(2018), technology tools were described as a tool to adapt classroom activities to provide efficient and excellent education. He further claimed that technology tools in the form of computer-based activities contribute wide array of resources including rapid and appropriate information to language learners. This denotes that technology tools especially search engines gift the students a lifetime opportunity of knowledge at the click of their fingertips. Conversely, Computer-assisted language learning (CALL) and Mobile assisted language learning (MALL) are reflection of technology integration making them the next limelight in the teaching process (Hashim et al., 2017). The writers further asserted that technology tools in the forms of mobile devices facilitates learning styles as technology is capable of personalizing learning according to the individual differences. Withal, Kwon and Lee (2010) propounded that technology tools play a key role as drill to help students practice language forms like vocabulary, expressions and communications anytime and anywhere.

Keeping up with the rapid growth of technology in the era of fourth industrial revolution, technology is also used as a tool and catalyst for change to enhance and assist learning. It could thus be established that the use of technology is underpinned by educational theories like cognitivism, behaviourism and constructivism (Imenda, 2018). Because technology is able to act as a stimulus in teaching and learning through which outcome like enhanced performance in academic can be obtained. As for cognitivism, technology allows students to be the active learner in gathering and retaining and applying the knowledge learnt. And with the gathered knowledge, students will be able to construct knowledge through the various technology tools which provides the students the opportunity to take charge of their own learning. Therefore, it could be noted that technology is influenced by these three overarching paradigms of educational learning theories where all three theories complement each other in incorporating technology in teaching and learning. 


\section{Past Researches on Technology Tools' usage in ESL Classroom}

As mentioned earlier with the growing impact of technology in the world and education, more and more researches were conducted, are being conducted and are to be conducted. This is also supported by Hashim and Md. Yunus (2012) who claimed that researches have been conducted in relation to technology which reported results that favours technology in English as second language teaching and learning. This is a novel process as technology is not limited to just one single entity. Explosions of technology tools are available and even more are being introduced. Hence, researches are conducted to understand them and even to explore the effectiveness of the available resources. For an instance, Hashim et al., (2019) and Rafiq et al., (2019) in their studies reported that using gamified-learning intervention; Socrative, PowerPoint Challenge game as well as Kahoot indicated significant improvement in students' grammar knowledge whereas Massive Open Online Course; an open online learning platform favours real life learning that is able to cater lifetime learning. The authors too upheld the use of apps or applications as it allows students to learn 'on the go' and thus allot self-directed practice to learn vocabulary. The technology tools in the form of apps were also analogized to a library and personal tutor as the tool is readily available anytime and anywhere.

Additionally, technology tools like applications that can be downloaded for free or even with a fee is perceived as an effective tool to develop vocabulary development among adult English as Second Language learners (Nisbet \& Austin, 2013). Likewise, Kaur et al., (2014) focussed on videos as a technology instructional tool and cognitive stimulator to help promoting retention among students. The study then pointed towards a conclusion that the use of video did not just favoured better quality written work but also higher interest level towards the lesson among students. The upshot of this is that the use of this form of technology tool as instructional tool has more benefits for students. Md Yunus and Suliman (2014) further highlighted characteristics of technology tools that underpin the quality of teaching and learning through the acclimatisation of self-sufficiency, competence and originality.

In another similar study conducted by Ramamuruthy and Rao (2015), it was identified that the use of high-technology specifically smartphone among adult ESL learners increased the learners' 4C's; critical and creative thinking, collaboration and communication skills and the use of the technology tool also deemed to increase the satisfaction level among the students. Arif et al., (2020) too proposed that extensive technological resources and tools supports and increases students' creativity, communication, collaboration, problem solving and critical thinking skills as this platform gives way to a limitless access to gen, information and knowledge via individualised ultimate learning. This is also accredited by Md Yunus and Suliman (2014), whom recognized the role of technology tools in enhancing the higher order thinking skills which is one of the most important $21^{\text {st }}$ century skills that students are required to get hold of to survive in this competitive world.

Correspondingly, the performance and competency in English writing among Malaysian students of different stages through the integration of various forms of technology tools were studied by Aziz et al., (2019); Basri et al., (2019); Jasni et al., (2019); Yih and Nah, (2009); Yunus, Salehi, and Chenzi, (2012); Yunus, Salehi, and Nordin, (2012). Among them social networking tools was explored by Yunus, Salehi, and Chenzi (2012) and the verdicts reported that integration had widened students' knowledge and heightened their enthusiasm and self-confidence in learning to write in ESL classroom. The study also highlighted disadvantages in terms of lack of equipment, access to internet and reduced 
interaction with teachers and thus recommended that it is crucial for students and teachers to have a grasp of technical skills in integrating technology. Yunus et al., (2013) on the other hand, identified that the use of technology tools was still low but it was also found that when ICT tools were used, students were attracted, learning was eased, vocabulary was improved and meaningful learning was favoured. However, the study also noted shortcomings in terms of class control, distraction, tendency to use short forms in writing as well as lack of competency among teachers in handling glitches and preparation of activities linking technology tools in their respective ESL teaching and learning.

Furthermore, researches were also conducted to investigate the effectiveness of using technology in speaking skill. Bahadorfar and Omidvar(2014) described technological tools as a vehicle to help students improve speaking skills. The authors also highlighted the use of technological tools like internet, podcasts, video conferencing, videos and speech recognition software like Technology Enhanced Language Learning, Podcasting, Quick Link Pen and Quicktionary among the best tools for teaching speaking skills. It was also noted that technology has the capability to encourage learners to engage in autonomous process for self-paced communication with added feature of feedback to help students to instantly amend mistakes made. On the other hand, Parveen (2016) also suggested that web applications as a tool allows students to interact and collaborate with others and thus provide the possibilities of enhancing communication skills through variety of communicative variances. Correspondingly, Cong-Lem (2018) reviewed empirical studies on the use of technology in developing speaking skills. The author thence provided clear cut findings that web-based technology provides linguistic inputs that enhance students' linguistic and background knowledge while blogs with audio and video promotes sharing of personal experiences that allows practices to speak. This author also highlighted the credibility of technology to be present across time and place which encourages students to engage in the language learning process continuously with lower anxiety while favouring active and encouraging environment.

Technology's integration in reading skill has also been a fertile field for many researchers. Marino (2009) reported findings of his study that had utilized cognitive tools in reading comprehension. It was emphasised that students who obtained poor percentile in reading assessment have also benefitted from the tools. In addition, Michael and Pilgrim, (2016) noted in their study that virtual reality tools provide an efficient and reasonable way to help students through visual and experiential scaffolding. The authors also indicated that technology tools aid students to learn new information to the content learnt. (Constantinescu (2007) on the other hand explored the benefits of computer assisted language learning (CALL) for vocabulary procurement and grasp of reading. The researcher highlighted the use of multimedia which was proved to have significantly helped students to read much better. The tools were also believed to help in learning, remembering and recalling new words which eventually help in comprehending what is read. It was therefore suggested that teachers get to know the many different types of software and online materials to ensure that the tool used has a direct and positive impact on students and their performance. And based on the review of a number of past researches, advantages and disadvantages of integrating technology tools in ESL classroom are outlined as below. 
Table 1 Advantages and Disadvantages of integrating technology tools in ESL classroom

\begin{tabular}{|c|c|}
\hline Advantages & Disadvantages \\
\hline $\begin{array}{l}\text { Technology favours learning regardless of } \\
\text { location and time thus promoting self-regulated } \\
\text { learning. }\end{array}$ & $\begin{array}{l}\text { There is a possibility for distraction and } \\
\text { misuse of technology in classroom. }\end{array}$ \\
\hline $\begin{array}{l}\text { Allows teachers and instructors to be creative } \\
\text { and innovative in designing interesting lessons. }\end{array}$ & Instability of internet connection \\
\hline $\begin{array}{l}\text { Technology is readily available and easy to } \\
\text { access thus promoting lifelong learning }\end{array}$ & $\begin{array}{l}\text { Technology could restrict thinking } \\
\text { potential among students as they are } \\
\text { limited to using limited tools. }\end{array}$ \\
\hline $\begin{array}{l}\text { Enhanced motivation could be seen among } \\
\text { students when technology was integrated. This } \\
\text { included motivation to complete homework, to } \\
\text { study and to be productive. }\end{array}$ & $\begin{array}{l}\text { Possibilities of technical issues like } \\
\text { instability of internet access and electricity } \\
\text { halter the teaching and learning process } \\
\text { and build frustration among students and } \\
\text { teachers. }\end{array}$ \\
\hline $\begin{array}{l}\text { Teachers are able to be experiment tools to help } \\
\text { making their lessons effective. }\end{array}$ & $\begin{array}{l}\text { Classroom control would be a problem } \\
\text { when it comes to a large group of students } \\
\text { and limited number of available devices. }\end{array}$ \\
\hline $\begin{array}{l}\text { Technology transforms the dynamics of } \\
\text { classrooms through the optimal learning } \\
\text { opportunities. }\end{array}$ & $\begin{array}{l}\text { Myriad of technology tools but lack of } \\
\text { exposure and usage among teachers. }\end{array}$ \\
\hline $\begin{array}{l}\text { Allows for a realistic approach or authentic } \\
\text { settings for teaching and learning to occur in a } \\
\text { genuine context. }\end{array}$ & $\begin{array}{l}\text { Efficiency in learning new knowledge and } \\
\text { skills is not guaranteed when teachers lack } \\
\text { the experience and knowledge to } \\
\text { integrate technology. }\end{array}$ \\
\hline $\begin{array}{l}\text { Integrating technology increases classroom and } \\
\text { academic performance. }\end{array}$ & $\begin{array}{l}\text { Large number of students makes it } \\
\text { difficult to allow all students to take part } \\
\text { simultaneously. }\end{array}$ \\
\hline $\begin{array}{l}\text { Technology promotes collaboration and } \\
\text { communication inside and outside of classroom. }\end{array}$ & Limited time to prepare for online learning \\
\hline $\begin{array}{l}\text { Technology opens up access for students for an } \\
\text { unrestricted access to diverse resources and } \\
\text { tools to develop learning. }\end{array}$ & \\
\hline $\begin{array}{l}\text { Allows channelling access to quality education } \\
\text { through quality resources. }\end{array}$ & \\
\hline Reduce the affective filter among students. & \\
\hline $\begin{array}{l}\text { Students have shown interest when technology } \\
\text { is incorporated in lessons. }\end{array}$ & \\
\hline $\begin{array}{l}\text { Technology promotes learner-centred situation } \\
\text { for learners. }\end{array}$ & \\
\hline $\begin{array}{l}\text { Technology tools allows for immediate feedback. } \\
\text { Technology promotes self-paced learning. }\end{array}$ & \\
\hline $\begin{array}{l}\text { Integrating technology in lessons results in } \\
\text { higher motivation, self-esteem and self- } \\
\text { confidence level amid learners. }\end{array}$ & \\
\hline
\end{tabular}




\begin{tabular}{|c|}
\hline $\begin{array}{l}\text { Technology in education increases technolog } \\
\text { skills among students and teachers. }\end{array}$ \\
\hline $\begin{array}{l}\text { Technology serves as a platform for active } \\
\text { learning whereby students' learning } \\
\text { engagement is increased. }\end{array}$ \\
\hline $\begin{array}{l}\text { Social skills are developed among students with } \\
\text { the aid of technology through peer } \\
\text { communication and collaboration. }\end{array}$ \\
\hline $\begin{array}{l}\text { Technology in teaching and learning is capable to } \\
\text { promote higher order thinking skills among } \\
\text { students. }\end{array}$ \\
\hline Students' enthusiasm to learn is increased. \\
\hline $\begin{array}{l}\text { Technology encourages independent } \\
\text { learning which develops students' ownership to } \\
\text { learning. }\end{array}$ \\
\hline $\begin{array}{l}\text { Technology in teaching increases students' } \\
\text { attention and retention in learning. }\end{array}$ \\
\hline
\end{tabular}

Based on the table, it is clear cut that, the advantages of integrating technology in ESL classroom outweigh the disadvantages. The benefits identified here are found to not be limited within the circle of students as it goes across and beyond the many stakeholders in education sector. This is especially true in the learning community which involves teachers and students because with technology, teachers do not just make their work easy and manageable but they are able to attract and motivate students to involve and perform in studies which is directly associated with better performance in students' grades. Therefore, it is unquestionable that integrating technology is definitely a go to tool to ensure effective teaching and learning.

\section{Issues and Challenges pertaining to the usage of Technology Tools}

Though technology has more to offer it is undeniable that even technology has two sides. Based on the researches read and understood, a number of issues and challenges were identified. Among them is that there is still lack of experimenting with technology tools in ESL teaching and learning. This is because, only a few technology tools are explored often by teachers which is probably due to lack of exposure. This is supported by Hannafin and Vermillion (2012); Safitry et al., (2015) and Seward and Nguyen (2019) whom claimed that there is lack of exposure and knowledge on how to apply ICT and there is still little knowledge about software or websites that support teaching among teachers. This brings to the next issue which is low level of awareness among educators on the availability of technology tools in ESL classroom. Without the introduction and training as well as validity of the technology tools in teaching and learning, teachers would be in doubt whether to use or not the technology tools as they fear if the use might cause problems and even fail the objective of the lesson. Carver (2016) andKamau et al., (2018) supported this notion by asserting in their studies that easy access to empirically authenticated educational technologies is crucial for effective implementation of technology in classroom and this becomes one of the reason behind teachers' willingness to integrate or to not integrate technology in their teaching and learning process. 
Following that is internal issues pertaining to fund including lack of access, inaccessibility of devices and lack of time. Lack of access here is referring to the internet access which is due to locality, internet availability and speed. Inaccessibility in this context refers to the inadequacy of computer rooms due to time constraints as well as insufficient computers. And finally, lack of time because the process involving ushering of students to and from computer labs, setting up labs, conducting the lesson, attending students to log in computer, especially when involving young children is a tiresome and long process which might lead the lesson to be incomplete.

Although there are challenges and issues pertaining to the use of technology tools in ESL classroom, it is true that the use of technology has even more advantages to both students and teachers. To overcome the challenges identified, researchers suggest that planning has to be done before hand. When planning is done, including the set up and instructions, time could be saved and even problems could also be foreseen and thus ideas to tackle the problem can be identified.

\section{Pedagogical Implications}

Technology and education are not apart. Hence, instead of claiming that technology is not suitable and that more problems arise with the assimilation of technology tools in teaching and learning, a comprehensive solution has to be identified to ensure that teachers are able to use technology tools that suit their classroom. Having clear cut ideas on what are available and what would be suitable, will conserve a lot of time for teachers and thus ensure the positive attitude among teachers in integrating technology tools successfully in their ESL classroom. This could be done by exploring millennial teachers' use of technology tools in their ESL classroom as this net generation teachers are claimed to be more technology savvy than teachers from previous generation. Therefore, getting this information will be a valuable data to be shared with other teachers. The sharing would definitely expand teachers' exposure on the effective technology tools and even help them to identify the right technology tools for their respective classrooms based on millennial teachers' experience of using the technology tools. Besides, the information could also serve as valid data as the shared technology tools are applied in their respective classroom and so is considered to be pilot tested already. Apart from that, the need to get to know the technology tools that are validated by teachers will help not just the stakeholders like Ministry of Education, State Education Department, District Education Department and even school adminstrationto impart the knowledge and to train their teachers to use technology identified to be effective for them. This in return would save a lot of time as the technology to be imparted are known to be efficient in ESL classroom. Therefore, the exposure to the many valuable technology tools used by millennial teachers would help in attracting the new generation of students who are almost all glued to technology to take part in the lesson not just in the classroom but during virtual classes as well. This in return will ensure that students are able to learn and acquire second language without much hiccups. It is thus appropriate to define technology as the perfect complementary tool to help in improving and facilitating language learning process as it is not just attractive and motivating for students but also provides rich environment for students to learn language.

\section{Conclusion}

Through this paper, the researcher had reviewed important concepts relavant to the use of technology tools in ESL classroom and how important millennial teachers are in exploring the 
use of technology tools. Through the review, it can be established that as definite that technology is inseparable from human's life especially when it comes to education as denoted by Rafiq et al., (2020) and Abdul Halim et al., (2020), it is also unavoidable to accept that millennial generation has higher capability and credibility when it comes to using technology (Hashim, 2018). Hence, delving into the use of technology among millennial teachers will be a fruitful source of information for not just teachers but all stakeholders in the education system. This is because, being hit by the sudden pandemic now has sparked a revelation of technology's importance in education among people of all walks of life, especially the government, education ministry, teachers, parents and students. The abrupt spread of covid19 which had halted the learning process and continuity for millions of students has evoked possibilities of continuing the learning through the aid of technology. However, in many countries including Malaysia, implementing online learning has brought realization that this method was not the best option due to various factors like lack of exposure, limited usage of technology and lack of access and choice of instructional practices (Fatimah et al., 2020). Therefore, it is recommended that to enhance the use of technology tools in ESL classroom, millennial teachers' perspectives and practices are to be explored as they are the right population to gather data from. Because, having an insight from this population will definitely serve as a good stepping stone for a higher integration of technology tools in ESL classroom in the future through which not just teachers but students too will gain maximum benefit from. For an instance, insight into generation $Y$ or millennial teachers experience on using myriad of technology in ESL classroom will contribute as a disclosure to other teachers on new yet authenticated technology used by other teachers which can be applied in their classroom for effective teaching and learning. On the other hand, getting to know millennial teachers' perspectives and practices will help stake holders to plan and develop programmes or modules on various technological resources to guide teachers to use different platforms rather than relying on just 4 or 5 technology that they already know about.

In this paper, it is revealed that technology has more advantages than disadvantages in for both teachers and students. It is an effective tool which comes handy for teachers and an attractive tool to not just fascinate students but to help stimulate and facilitate active language learning for students. However, the multitude of technology tools available today makes it difficult for teachers to choose the right tool to be used in classroom. Therefore it is appropriate to support teachers by providing a list of desirable and practical technology tools which are used and validated by teachers who are known to be technology savvy, the millennial teachers. With the aid from millennial teachers, the exponential function of technology tools can be exposed to teachers to be used in their respective ESL classroom And most importantly, this will also prepare teachers and students to be ready in worst case scenario of having to go through similar pandemic again in the future. At that time, distance learning, online learning, blended learning and continuous learning would not be an alien thing but a practiced norm for the respected parties ensuring the continuity of learning is not disrupted.

\section{Acknowledgement}

The authors would like to thank Universiti Kebangsaan Malaysia under the Research Grant number (i) GG-2020-027 (ii) GG-2019-017 for supporting this research. 


\section{References}

Ahmadi, M. R. (2018). The Use of Technology in English Language Learning: A Literature Review. International Journal of Research, 3, 115-125.

Alexander, A. (2012). Understanding and meeting the needs of the millennials in the Understanding and meeting the needs of the millennials in the classroom: A literature review classroom: A literature review. Graduate Research Papers, 123, 1-35. https://scholarworks.uni.edu/grp/123

Arif, F. K. M., Affendi, F. R., Noah, J. B., \& Yunus, M. M. (2020). Innovative trends and practices in ESL for education 4.0 among higher learning institutions. International Journal of Scientific and Technology Research, 9(3), 4027-4030.

Aziz, N., Hashim, H., \& Yunus, M. M. (2019). Using Social Media to Enhance ESL Writing Skill among Gen-Z Learners. Creative Education, 10(12), 3020-3027. https://doi.org/10.4236/ce.2019.1012226

Bahadorfar, M., \& Omidvar, R. (2014). Technology In Teaching Speaking Skill. Acme International Journal of Multidisciplinary Research, 9-13. http://www.aijmr.net

Basri, H., Hashim, H., \& Yunus, M. (2019). Using Google Apps as Learning Strategy to Enhance ESL Writing. Creative Education, 10(2008), 2649-2657. https://doi.org/10.4236/ce.2019.1012192

Carver, L. B. (2016). Teacher perception of barriers and benefits in K-12 technology usage. Turkish Online Journal of Educational Technology, 15(1), 110-116.

Celi, C. (2019). Millennials or Digital Natives: Consuming and Producing News from Activism. Journal of Applied Business and Economics, 21(9), 14-23.

Cong-Lem, N. (2018). Web-Based Language Learning (WBLL) for Enhancing L2 Speaking Performance: A Review. Advances in Language and Literary Studies, 9(4), 143-152.

Constantinescu, A. I. (2007.). Using Technology to Assist in Vocabulary Acquisition and Reading Comprehension The Internet TESL Journal, 13(2).

Rahman, S. F. A., Yunus, M. M., \& Hashim, H. (2020). The Uniqueness of Flipped Learning Approach. International Journal of Education and Practice, 8(3), 394-404.

Hannafin, R. D., \& Vermillion, J. R. (2012). Technology in the Classroom. In 21st Century Education: A Reference Handbook 21st century education: A reference handbook (pp. II209-II-218). SAGE Publications, Inc. https://doi.org/10.4135/9781412964012.n73

Hashim, H. (2018). Application of Technology in the Digital Era Education. International Journal of Research in Counseling and Education, 1(2), 1. https://doi.org/10.24036/002za0002

Hashim, H., Md. Yunus, M., Embi, A. M., \& Ozir, M. N. A. (2017). Mobile-assisted Language Learning (MALL) for ESL Learners: A Review of Affordances and Constraints. Sains Humanika, 9(1-5), 45-50. https://doi.org/10.11113/sh.v9n1-5.1175

Hashim, H., Rafiq, K. R., \& Yunus, M. M. (2019). Improving ESL Learners' Grammar with Gamified-Learning. Arab World English Journal (AWEJ), 5, 41-50.

Hashim, H., Yunus, M. M., \& Embi, M. A. (2016). Pre-University English as Second Language (ESL) Learners' Attitude towards Mobile Learning. Creative Education, 07(08), 11471153. https://doi.org/10.4236/ce.2016.78119

Imenda, S. N. (2018). On the Unity of Behaviourism, Cognitivism and Constructivism in Teaching and Learning. Int J Edu Sci, 20, 86-95. https://doi.org/10.1080/09751122.2017.1334399

Jasni, N. S., Hashim, H., Md Yunus, M., \& Rahman, S. F. A. (2019). Distance Learning via MOOCs: Improving ESL Learners' Writing Skills. Journal of Physics: Conference Series, 
1424(1). https://doi.org/10.1088/1742-6596/1424/1/012031

Kamau, L. M., Mwania, J., \& Njue, A. K. (2018). Technology Resources For Teaching Secondary Mathematics: Lessons From Early And Late Adopters Of Technology In Kenya. Asian Journal of Contemporary Education, 2(1), 43-52.

https://doi.org/10.18488/journal.137.2018.21.43.52

Kaur, D., Yong, E., Zin, M. N., \& Dewitt, D. (2014). The Use of Videos as a Cognitive Stimulator and Instructional Tool in Tertiary ESL Classroom. In The Malaysian Online Journal of Educational Technology (Vol. 2, Issue 3). Kotz, P. E. (2016). Reaching the Millennial Generation in the Classroom. Universal Journal of Educational Research, 4(5), 1163-1166. https://doi.org/10.13189/ujer.2016.040528

Kwon, S., \& Lee, J. E. (2010). Design principles of m-learning for ESL. Procedia-Social and Behavioral Sciences, 2(2), 1884-1889. https://doi.org/10.1016/j.sbspro.2010.03.1003

Marino, M. T. (2009). Understanding How Adolescents with Reading Difficulties Utilize Technology-Based Tools. Exceptionality, 88-102. https://doi.org/10.1080/09362830902805848

Masrop, N. A. M., Ishak, H., Zainuddin, G., Ramlan, S. R., Sahrir, M. S., \& Hashim, H. (2019). Digital Games Based Language Learning for Arabic Literacy Remedial. Creative Education, 10(12), 3213-3222. https://doi.org/10.4236/ce.2019.1012245

Md Yunus, M., Hashim, H. U., Makhtar, R., Norman, H., \& Hashim, H. (2020). The voyage of ESL learners' English language learning in the era of post-colonialism: $A$ thematic analysis. Humanities and Social Sciences Letters, 8(2), 224-229. https://doi.org/10.18488/journal.73.2020.82.224.229

Yunus, M. M., \& Suliman, A. (2014). Information \& communication technology (ICT) tools in teaching and learning literature component in Malaysian secondary schools. Asian Social Science, 10(7), 136. https://doi.org/10.5539/ass.v10n7p136

Michael, J., \& Pilgrim, J. (2016). The Use Of Virtual Reality Tools In The Reading-Language Arts Classroom. Texas Journal of Literacy Education, 4(2), 90-97. https://www.google.com/edu/expeditions/

Nisbet, D., \& Austin, D. (2013). Enhancing ESL Vocabulary Development through the Use of Mobile Technology. Journal of Adult Education, 42, 1-7. https://eric.ed.gov/?id=EJ1047363

Noguera, I. (2014). How Millennials are changing the way of learning: the state of the art of ICT integration in education. RIED. Revista Iberoamericana de Educación a Distancia, 18(1).

Parveen, B. W. (2016). Use Of Technology In Improving Speaking Skills. Journal Of English Language And Literature (JOELL) , 3(2), 121-124. http://www.joell.in

Pazilah, F. N. P., Hashim, H., \& Yunus, M. M. (2019). Using Technology in ESL Classroom: Highlights and Challenges. Creative Education, 10(12), 3205-3212. https://doi.org/10.4236/ce.2019.1012244

Rafiq, K. R. M., Hashim, H., \& Pazilah, F. N. (2019). Developing a MOOC for Communicative English: A Battle of Instructional Designs. In International Journal of Innovation, Creativity and Change. www.ijicc.net (Vol. 7, Issue 7). www.ijicc.net

Rafiq, R. K. M., Nor Pazilah, F., Tong, Y. G., Md Yunus, M., \& Hashim, H. (2020). Game On! Development And Evaluation Of Computer Games For ESL Classroom. INTERNATIONAL JOURNAL OF SCIENTIFIC \& TECHNOLOGY RESEARCH, 9, 2. www.ijstr.org

Ramamuruthy, V., \& Rao, S. (2015). Smartphones Promote Autonomous Learning in ESL Classrooms. Malaysian Online Journal of Educational Technology, 3(4), 23-35. 
www.mojet.net

Safitry, T. S., Mantoro, T., Ayu, M. A., Mayumi, I., Dewanti, R., \& Azmeela, S. (2015). Teachers' perspectives and practices in applying technology to enhance learning in the classroom. International Journal of Emerging Technologies in Learning, 10(3), 10-14. https://doi.org/10.3991/ijet.v10i3.4356

Dedo, S. F., \& Hashim, H. (2019). Interactive ICT Language Games in Encouraging Active Learning among the Suburban ESL Learners. International Journal of Academic Research in Business and Social Sciences, 9(12). https://doi.org/10.6007/IJARBSS/v9i12/6764

Schwartz, A. C., McDonald, W. M., Vahabzadeh, A. B., \& Cotes, R. O. (2018). Keeping Up With Changing Times in Education: Fostering Lifelong Learning of Millennial Learners. FOCUS, 16(1), 74-79. https://doi.org/10.1176/appi.focus.20170004

Seward, T. P., \& Nguyen, H. T. (2019). The Digital Imperative in the 21st Century Classroom Rethinking the Teacher-Learner Dynamic. In itejournal.org. http://www.itejournal.org/issues/spring-2019/06seward\&nguyen.pdf

Halim, M. S. A. A., Hashim, H., \& Yunus, M. M. (2020). Pupils' Motivation and Perceptions on ESL Lessons through Online Quiz-Games. Journal of Education and E-Learning Research, 7(3), 229-234.https://doi.org/10.20448/journal.509.2020.73.229.234

Yunus, M. M., Nordin, N., Salehi, H., Embi, M. A., \& Salehi, Z. (2013). The Use of Information and Communication Technology (ICT) in Teaching ESL Writing Skills. English Language Teaching, 6, 1-8. https://eric.ed.gov/?id=EJ1077058

Yunus, M. M., Salehi, H., \& Chenzi, C. (2012). Integrating Social Networking Tools into ESL Writing Classroom: Strengths and Weaknesses. English Language Teaching, 42-48. https://eric.ed.gov/?id=EJ1079801

Yunus, M. M., Salehi, H., \& Nordin, N. (2012). ESL pre-service teachers' perceptions on the use of paragraph punch in teaching writing. English Language Teaching, 5(10), 138146. https://doi.org/10.5539/elt.v5n10p138

Yunus, M., Hashim, H., \& Jusoff, K. (2010). ESI Lecturers' Voices on Tell Me More. Studies in Literature ..., 1(1), 69-84. http://50.22.92.12/index.php/sll/article/view/1396 